\title{
Comparative study of hypoglycemic activity of Morus alba with oral glibenclamide in streptozotocin induced diabetic rats
}

\author{
Mamatha Reddy ${ }^{1}$, Altaf Hussain Shaik ${ }^{2 *}$
}

${ }^{1}$ Department of Pharmacology, Kurnool Medical College and Hospital, Kurnool, Andhra Pradesh Province, India ${ }^{2}$ Department of Pharmacology, Nimra Institute of Medical Sciences, Jupudi, Vijayawada, Andhra Pradesh, India

Received: 28 December 2018 Accepted: 29 January 2019

\section{*Correspondence to:}

Dr. Altaf Hussain Shaik, Email: dr.althaf71@gmail.com

Copyright: (C) the author(s), publisher and licensee Medip Academy. This is an openaccess article distributed under the terms of the Creative Commons Attribution NonCommercial License, which permits unrestricted noncommercial use, distribution, and reproduction in any medium, provided the original work is properly cited.

\begin{abstract}
Background: Diabetes is a chronic metabolic disorder that continues to present a major worldwide health problem, characterized by absolute or relative deficiencies in insulin secretion and/or insulin action associated with chronic hyperglycaemia and disturbances of carbohydrate, lipid, and protein metabolism. It is fast growing disease, gains the status of a potential epidemic in India with prevalence of more than 62 million diabetic individuals currently diagnosed with the diabetes.

Methods: The study was conducted at Department of Pharmacology, Kurnool Medical College, Kurnool for a period of 1 year from January 2017 to December 2018. Animals used were albino rats, of Wistar strain, weighing between 150$200 \mathrm{gm}$ of either sex. The animals were divided into six groups as: control group (I); pathogenic control group (II) injected intravenously (i.v.) with single dose of STZ (60mg/kg); Morus alba stem bark extract (group-III; 200mg/kg), and groupIV $(400 \mathrm{mg} / \mathrm{kg})$; group-V animals treated with glibenclamide $(5 \mathrm{mg} / \mathrm{kg}$, p.o.) following STZ treatment; group-VI, animals treated with bark extract per se (400 $\mathrm{mg} / \mathrm{kg}$ ).
\end{abstract}

Results: The results of this study showed a significant decrease blood glucose level, glycosylated heamoglobin level, and reduction in glutathione and insulin level after STZ administration. These parameters were significantly $(p<0.05)$ reversed by extracts dose dependently.

Conclusions: Thus, authors conclude that $M$. alba stem bark extracts produced significant antidiabetic and antioxidant effect which might be due to the presence of bioactive components such as phenolic and flavonoid content in the extract. The study warrants the need for further evaluated in certain other models of diabetes.

Keywords: Diabetes, Glibenclamide, Morus alba stem, STZ

\section{INTRODUCTION}

Diabetes is a chronic metabolic disorder that continues to present a major worldwide health problem, characterized by absolute or relative deficiencies in insulin secretion and/or insulin action associated with chronic hyperglycaemia and disturbances of carbohydrate, lipid, and protein metabolism. ${ }^{1}$ It is fast growing disease, gains the status of a potential epidemic in India with prevalence of more than 62 million diabetic individuals currently diagnosed with the diabetes. ${ }^{2}$ Globally diabetes is considered as most common and largest endocrine disorder and it is the fifth leading cause of death in the world. ${ }^{3,4}$ Wild et al, reported the prevalence of diabetes is predicted to double globally from 171 million in 2000 to 366 million in 2030 with a maximum increase in India. ${ }^{5,6}$ It has been reported in both preclinical and clinical studies that oxidative stress plays an important role in the pathogenesis of both types of diabetes mellitus. ${ }^{7}$ There is disproportionate production of free radicals in diabetes due to oxidation of glucose, nonenzymatic glycation of proteins, followed by subsequent oxidative degradation of 
glycated proteins. Insulin resistance as result of increased lipid peroxidation is associated with abnormally high levels of free radicals and the simultaneous decline of antioxidant defense mechanisms can lead to damage of cellular organelles and enzyme. The development of complications of diabetes is the consequence of high oxidative stress in both types of diabetes. ${ }^{8}$

Streptozotocin (STZ), an antibiotic produced by Streptomyces achromogenes, clinically used for the treatment of certain cancers of the Islets of Langerhans because of its selective toxicity to the insulin producing $\beta$ cells of pancreas. Therefore, it has been widely used in medical research for induction of type 1 diabetes in a variety of animals by affecting degeneration and necrosis of pancreatic $\beta$-cells. ${ }^{9}$ Ample of accumulating evidence suggests that free radicals play a crucial role in the streptozotocin-induced diabetes. In addition, it has been reported that streptozotocin produced oxidative stress and depletion of antioxidant systems in both blood and tissues particularly, liver. ${ }^{10}$ Moreover, Kedziora et al, found a reduction in antioxidant systems and elevation in lipid peroxidation in kidney of streptozotocin-induced diabetic rats. ${ }^{6}$

The genus Morus, consists of over 150 species; among them, $M$. alba is predominant species, found in temperate to subtropical regions of the Northern hemisphere to the tropics of the Southern hemisphere. M. alba Linn commonly known as white mulberry belongs to family Moraceae is also known as Tut in India. It is cultivated throughout the world, wherever silkworms are raised. Several parts of $M$. alba have been reported for their medicinal importance particularly in Ayurveda and in folklore. M. alba has gained the status of nature's functional tonic because of its unique nutritional profile containing proteins, phenolics, flavonoids and anthocyanins. Its bark, fruits, and leaves have been used also in both conventional and natural medicine. Mulberry plant extract has been reported in various experimental studies to exhibit potent antioxidant activity, antitumor activity, hypolipidemic effect, macrophage activating effect, and neuroprotective activity. The bark of the large stem is brown, rough, fissures mostly vertical, considered as vermifuge and purgative. Furthermore, polyphenolic compounds especially the flavonoids and among the flavonoids quercetin 3-(6-malonylglucoside) is most significant for antioxidant potential of mulberry plant. To our knowledge, there were no reports regarding the hypoglycemic effect of $M$. alba stem bark. Therefore, it is interesting to elucidate the antidiabetic effect of $M$. alba stem bark extracts in experimentally induced diabetes in animals.

\section{METHODS}

The study was conducted at Department of Pharmacology, Kurnool Medical College, Kurnool for a period of 1 year from January 2017 to December 2018. Animals used were albino rats, of Wistar strain, weighing between 150-200 gm of either sex.

Streptozotocin was purchased from Cipla limited. mumbai, Glibenclamide was obtained as gift from Panacea Biotech, Baddi, and Himachal Pradesh, India. Serum insulin ELISA kits for rats were purchased from Genxbio, manufactured by Cusabiotech. Blood glucose level was measured using commercial diagnostic kits manufactured by SPAN diagnostics, Surat, India. Whereas glycosylated haemoglobin level in whole blood sample was measured by the methods recommended by Reckon diagnostics, Gujrat, India. All other reagents and chemicals used in this study were of analytical grade.

\section{Preparation of the stem bark extract}

The stem bark of Morus alba L. was procured from Rawal HerMed consultants, New Delhi, India. The air-dried powdered stem bark $(2 \mathrm{~kg})$ of $M$. alba were defatted with petroleum ether $\left(60-80^{\circ} \mathrm{C}\right)$ in a soxhlet extractor and then with chloroform. The defatted material was further extracted exhaustively with $70 \%$ ethanol at ambient temperature. The ethanolic extract was concentrated in rotary evaporator at $35-40^{\circ} \mathrm{C}$ under reduced pressure. The concentrate is stored at $2-8^{\circ} \mathrm{C}$ until the completion of pharmacological studies. $100 \mathrm{mg}$ of $M$. alba stem bark extract was suspended in $0.5 \mathrm{ml}$ distilled water and administered orally to the rats through an intragastric tube at a dose of $200 \mathrm{mg} / \mathrm{kg}$ and $400 \mathrm{mg} / \mathrm{kg}$ body weight. The vehicle was used as a control throughout the study.

\section{Animals}

Male wistar albino rats (150-200g) were raised from animal facility of Mahavir enterprises, Hyderabad, India. They were housed in polypropylene cages ( 6 animals per cage) under natural light-dark cycle. The animals were fed with standard pellet diet (Amrut rat and mice feed, Pune, India) and allowed to drink water ad libitum. The animals were treated in the most humane and ethically acceptable manner with maximum care to ensure that the animals were treated.

\section{Experimental protocol}

Diabetes was induced in overnight fasted animals by STZ. The STZ was dissolved in freshly prepared citrate buffer $(0.1 \mathrm{~mol} / \mathrm{ml}, \mathrm{pH} 4.5)$. The blood glucose was measured after 3 days following the STZ administration to confirm the induction of diabetes. The rats were divided at random into six groups of 6 animals each. Group I animals served as normal control (received normal saline only). Group II as toxic control, treated with STZ $(60 \mathrm{mg} / \mathrm{kg}$, i.v.). The animals of group-III, IV were treated with graded doses (200 and $400 \mathrm{mg} / \mathrm{kg}$ respectively) of ethanolic extract of $M$. alba stem bark. Glibenclimide was administered at dose of $5 \mathrm{mg} / \mathrm{kg}$ to positive control animals (group V). Animals of group VI were treated with MASBE $(400 \mathrm{mg} / \mathrm{kg})$ per se. The animals of group II-V were made diabetic by injection 
of a single dose of STZ ( $60 \mathrm{mg} / \mathrm{kg}$; i.v.). STZ-treated rats were given $5 \%$ glucose in their drinking water for the first $24 \mathrm{~h}$ to counter any initial hypoglycemia. Urine glucose level was checked on day third of STZ administration by using enzymatic test strips. The drug treatment lasted for 21 days after the induction of diabetes. Blood sample was collected for biochemical estimation in serum and finally the animals were sacrificed under ether anesthesia for dissection of pancreas for biochemical measurements in tissue and histopathological studies on the last day of treatment.

\section{Statistical analysis}

All the data expressed as mean \pm SEM were analysed by One-way Analysis of Variance (ANOVA) followed by Dunnett's t test for multiple comparison. The statistical analyses were performed using Graphpad Prism 3.0. P values $<0.05$ were considered as statistically significant.

\section{RESULTS}

Administration of STZ resulted in significant $(\mathrm{p}<0.05)$ increase in mean blood glucose level on day 0 and day 21 (group-II) as compared to normal control animals (groupI). Post treatment with M. alba stem bark extract in STZ treated rats significantly reduced the increased blood glucose level as compared to group-II. Although the extract produced dose dependent effect, but the lowering of mean blood glucose was statistically insignificant with lower dose $(200 \mathrm{mg} / \mathrm{kg}$; p.o.) of $M$. alba stem bark extract. However, per se treatment with MASBE did not produce any significant effect on blood glucose level. Treatment with glibenclamide after induction of diabetes significantly ( $\mathrm{p}<0.05$ ) reduced the increased blood glucose level as compared to group-II (Table 1).

Table 1: Effect of Morus alba stem bark extracts on blood glucose in STZ-induced diabetic.

\begin{tabular}{|c|c|c|}
\hline \multirow{2}{*}{ Treatment group } & $\begin{array}{l}\text { Glucose } \\
\text { (mg/dl) }\end{array}$ & $\begin{array}{l}\text { Glucose } \\
\text { (mg/dl) }\end{array}$ \\
\hline & (day 0) & (Day 21) \\
\hline $\begin{array}{l}\text { Normal saline } \\
(1 \mathrm{mg} / \mathrm{kg}, \mathrm{p} . \mathrm{o})\end{array}$ & $60 \pm 1.32$ & $63.23 \pm 1.49$ \\
\hline STZ (40mg/kg, i.v) & $294.12 \pm 14.12$ & $305.2 \pm 15.23$ \\
\hline $\begin{array}{l}\text { STZ+MASBE } \\
(200 \mathrm{mg} / \mathrm{kg}, \text { p.o })\end{array}$ & $215.2 \pm 5.32$ & $175.2 \pm 3.55$ \\
\hline $\begin{array}{l}\text { STZ+MASBE } \\
(400 \mathrm{mg} / \mathrm{kg}, \text { p.o })\end{array}$ & $186.5 \pm 7.56$ & $81.34 \pm 1.66$ \\
\hline $\begin{array}{l}\text { STZ+Glibenclamide } \\
(5 \mathrm{mg} / \mathrm{kg}, \text { p.o })\end{array}$ & $143.35 \pm 12.5$ & $63.75 \pm 2.32$ \\
\hline $\begin{array}{l}\text { MASBE per } \\
\text { se }(400 \mathrm{mg} / \mathrm{kg}, \mathrm{p} . \mathrm{o})\end{array}$ & $65.8 \pm 2.15$ & $63.3 \pm 2.13$ \\
\hline
\end{tabular}

Administration of STZ (60mg/kg; i.v.) significantly ( $\mathrm{p}$ $<0.05)$ raised the level of glycosylated haemoglobin (HbA1C) in pathogenic control (group-II) as compared to normal control (group-I). Post-treatment with MASBE
(200, 400mg/kg; p.o.) reverses the HbA1C level as compared to pathogenic control group in dose dependent manner. The reduction of HbA1C level with MASBE $(200 \mathrm{mg} / \mathrm{kg})$ was statistically insignificant. However, glibenclamide significantly $(\mathrm{p}<0.05)$ reduced the $\mathrm{HbA} 1 \mathrm{C}$ level whereas MASBE per se did not produce any significant change in HbA1C level as compared to control group.

Table 2: Effect of Morus alba stem bark extracts on HbA1C and serum insulin in STZ-induced diabetic rats.

\begin{tabular}{|lll|}
\hline Treatment group & HbA1C & $\begin{array}{l}\text { Insulin } \\
\text { (ng/ml) }\end{array}$ \\
\hline $\begin{array}{l}\text { Normal saline } \\
(1 \mathrm{mg} / \mathrm{kg}, \mathrm{p} . \mathrm{o})\end{array}$ & $6.13 \pm 0.085$ & $0.14 .56 \pm 0.06$ \\
\hline STZ (40mg/kg, i.v) & $15.12 \pm 0.387$ & $0.75 \pm 0.65$ \\
\hline $\begin{array}{l}\text { STZ+MASBE } \\
(200 \mathrm{mg} / \mathrm{kg}, \mathrm{p} . \mathrm{o})\end{array}$ & $11.12 \pm 0.42$ & $0.082 \pm 0.05$ \\
\hline $\begin{array}{l}\text { STZ+MASBE } \\
(400 \mathrm{mg} / \mathrm{kg}, \mathrm{p} . \mathrm{o})\end{array}$ & $6.972 \pm 0.28$ & $0.12 \pm 0.0017$ \\
\hline $\begin{array}{l}\text { STZ+Glibenclamide } \\
(5 \mathrm{mg} / \mathrm{kg}, \text { p.o) }\end{array}$ & $6.46 \pm 0.85$ & $0.13 \pm 0.01$ \\
\hline $\begin{array}{l}\text { MASBE per } \\
\text { se (400mg/kg, p.o) }\end{array}$ & $6.022 \pm 0.22$ & $0.146 \pm 0.0037$ \\
\hline
\end{tabular}

\section{DISCUSSION}

The objective of treatment in diabetic patient is to lower blood glucose to normal level. In the present study, M. alba stem bark extract (MASBE) showed significant lowering of blood glucose level, an index of diabetic control. STZinduced diabetes is one of the widely used animal models that mimic the human diabetes mellitus. The selective destruction of insulin-producing $\beta$-cells of the pancreas by STZ is mediated by induction of high levels of DNA strand breaks in these cells, causing activation of poly (ADPribose) polymerase (PARP), resulting in reduction of cellular NAD+, and cell death. The metabolism of glucose, proteins and lipids is abnormal in diabetes due to insulin secretion defect, leading to various metabolic disorders and complications. In addition, STZ generates potential free radicals such as nitric oxide (NO) by intracellular metabolism of STZ and precipitate further $\beta$-cells DNA damage by strand break. ${ }^{7}$

The concentration of blood glucose was significantly increased in diabetic as compared with STZ as compared to normal control. Administration of MASBE $(200 \mathrm{mg} / \mathrm{kg}$ and $400 \mathrm{mg} / \mathrm{kg}$ ) significantly reduced the raised blood glucose level in STZ induced diabetic rats and the lowering was almost comparable to glibenclamide ( $5 \mathrm{mg} / \mathrm{kg}$, p.o.). ${ }^{8}$ Further, this antidiabetic activity of MASBE was associated with an increase in the serum insulin level revealed that MASBE may stimulate insulin secretion from regenerated $\beta$ cells and remaining $\beta$-cells. The blood glucose lowering effect of the extract could be due to the presence of terpenoid compounds as reported by the 
previous study. These findings were also supported by the previous experimental findings wherein they reported the blood glucose lowering effect of triterpenoids from Psidium guajava leaves. ${ }^{9}$

Glycated haemoglobin (HbA1c) is a routinely used as a marker for long-term glycemic control. Persistent hyperglycemia in diabetes manifest as increased HbA1C level as a result of glycation of haemoglobin. Diabetic patients were reported with increased level of $\mathrm{HbA} 1 \mathrm{C}$ upto $16 \%$. The raised HbA1C level well correlates with the complication such as diabetic retinopathy, nephropathy, and neuropathy. $10 \mathrm{In}$ addition, there is relative deficiency of insulin leads to decreased protein synthesis in all tissues consequently reduced synthesis of haemoglobin in diabetes. Thus, the findings of the present study showed that administration of MASBE $(200,400 \mathrm{mg} / \mathrm{kg}$ ) significantly decreased the raised HbA1C level in STZinduced diabetic rats. However, per se treatment (MASBE alone) did not produce significant change in HbA1C level. Present study findings were in agreement with previous study reported the restoration of raised $\mathrm{HbA} 1 \mathrm{C}$ level after treatment with Tectona grandis flower extract in STZinduced diabetic rats.

\section{CONCLUSION}

Thus, we conclude that $M$. alba stem bark extracts produced significant antidiabetic and antioxidant effect which might be due to the presence of bioactive components such as phenolic and flavonoid content in the extract. The study warrants the need for further evaluated in certain other models of diabetes.

Funding: No funding sources Conflict of interest: None declared

Ethical approval: The study was approved by the Institutional Ethics Committee

\section{REFERENCES}

1. Kumar A, Goel MK, Jain RB, Khanna P, Chaudhary V. India towards diabetes control: Key issues. Australasian Med J. 2013;6(10):524.

2. Gispen WH, Biessels GJ. Cognition and synaptic plasticity in diabetes mellitus. Trends Neurosci. 2000 Nov 1;23(11):542-9.
3. Wild S, Roglic G, Green A, Sicree R, King H. Global prevalence of diabetes: estimates for the year 2000 and projections for 2030. Diab Care. 2004 May $1 ; 27(5): 1047-53$.

4. Merzouk H, Madani S, Sari DC, Prost J, Bouchenak $\mathrm{M}$, Belleville J. Time course of changes in serum glucose, insulin, lipids and tissue lipase activities in macrosomic offspring of rats with streptozotocininduced diabetes. Clin Sci. 2000 Jan 1;98(1):21-30.

5. Sefi M, Fetoui H, Lachkar N, Tahraoui A, Lyoussi B, Boudawara $\mathrm{T}$, et al. Centaurium erythrea (Gentianaceae) leaf extract alleviates streptozotocininduced oxidative stress and $\beta$-cell damage in rat pancreas. J Ethnopharmacol. 2011 May $17 ; 135(2): 243-50$.

6. Kędziora-Kornatowska K, Szram S, Kornatowski T, Szadujkis-Szadurski L, Kędziora J, Bartosz G. The effect of verapamil on the antioxidant defence system in diabetic kidney. Chem Clin Acted. 2002 Aug 1;322(1-2):105-12.

7. Modak M, Dixit P, Londhe J, Ghaskadbi S, Devasagayam TP. Recent advances in Indian herbal drug research guest editor: Thomas Paul Asir Devasagayam Indian herbs and herbal drugs used for the treatment of diabetes. J Clin Biochem Nutr. 2007;40(3):163-73.

8. Patil R, Patil R, Ahirwar B, Ahirwar D. Current status of Indian medicinal plants with antidiabetic potential: a review. Asian Pacific J Trop Biomed. 2011 Oct 1;1(2):S291-8.

9. Butt MS, Nazir A, Sultan MT, Schroën K. Morus alba L. nature's functional tonic. Trends Food Sci Tech. 2008 Oct 1;19(10):505-12.

10. Yang X, Yang L, Zheng H. Hypolipidemic and antioxidant effects of mulberry (Morus alba L.) fruit in hyperlipidaemia rats. Food Chem Toxicol. 2010 Aug 1;48(8-9):2374-9.

Cite this article as: Reddy M, Shaik AH.

Comparative study of hypoglycemic activity of Morus alba with oral glibenclamide in streptozotocin induced diabetic rats. Int J Basic Clin Pharmacol 2019;8:545-8. 